\title{
Ethics - dentistry and tooth-drawing in the late eighteenth and early nineteenth centuries in England. Evidence of provision at all levels of society
}

\author{
M. G. H. Bishop, ${ }^{1,2}$ S. Gelbier, ${ }^{3}$ and D. Gibbons ${ }^{4}$
}

The popularity of caricature at the end of the eighteenth century allows a researcher to observe the social as well as the technical side of dentistry as it was then available throughout the kingdom. The value of these caricatures is further enhanced by the unconscious inclusion of everyday objects which a narrative account would not think it worthwhile including, even if such narrative account had existed.

\begin{abstract}
$T^{t}$ is a shame that there are so few English prints on the subject. The British Museum's Catalogue of political and personal satires lists just ten in its collection of over eight and a half thousand prints covering the period considered in this essay, and two of these are repeats. The Royal College of Surgeons of England has a Rowlandson print, as does the National Library of Medicine, Bethesda USA, which Malvin Ring illustrates in his enjoyable book Dentistry, an illustrated history, ${ }^{16}$ published in 1985, along with a further four early English prints. One is in the Northwestern University Dental School, Chicago; a superb illustrated broadside ballad of 1796 is in the collection of Dr. Bernard S. Moskow, another print is in the collection of the Bundesverband der Deutschend Zahnärzte, Cologne, and the fourth is in the Francis A Countway Library of Medicine, Harvard Medical Library / Boston Medical Library, Boston.
\end{abstract}

\footnotetext{
$\overline{1}^{\star}$ General Dental Practitioner, Queen Anne House, $2 a$ St. Andrew Street, Hertford, Hertfordshire SG14 3NS; ${ }^{2}$ PhD Student; ${ }^{3}$ Professor of Dental Public Health, Head of Division, Division of Dental Public Health, Oral Health Services Research and The Schools of Dental Nursing, Guy's King's and St Thomas' Dental Institute, King's Denmark Hill Campus, Caldecot Rd, Denmark Hill, London SE5 9RW; ${ }^{4}$ Professor, Division of Dental Public Health, Oral Health Services

Research and The Schools of Dental Nursing, Guy's

King's and St Thomas' Dental Institute, Guy's Campus

${ }^{*}$ Correspondence to: Malcolm Bishop

REFEREED PAPER

Received 09.04.01; Accepted 30.07.01

(C) British Dental Journal 2001; 191: 575-580
}

The roots of dentistry edited by Christine Hillam and published by the BDA in $1990^{17}$ identifies a further two prints; one in R.A. Cohen's collection, and the other with an undeclared location. The museum of the British Dental Association (BDA) has four more on display.

Fortunately, with or without permission, two early nineteenth century engravers and publishers took earlier works and either copied or re-worked them. Edward Orme of London, an accomplished artist, published at least four in 1810, Acute pain, Fellow feeling, Mirth and anguish, and Laughter and experiment. The original for Mirth and anguish may be seen at the BDA museum in a 1773 print entitled Acute pain by Timothy Dobbin. Fellow feeling, one of the prints used in this essay, uses characters first seen in prints variously attributed to Harris and Dixon in 1768, and Dighton in 1791.

William Davison of Alnwick, a much more crude engraver than Orme, copied or re-worked at least three dental prints in his series published between 1812 and 1817 entitled Some Alnwick caricatures. Two of these are directly attributable to prints by Dighton from 1784, and one is a possible reworking of another by the same artist of 1771. This last seems to be little known, and in this environment of scarcity, any survival is most welcome.

By the late eighteenth century, all classes had available to them relief of dental pain by extraction, and those well to do enough could be provided with replacement teeth. The cartoon (Fig. 1) by Thomas Rowlandson illustrates the use of the title Dentist in 1787 used by a practitioner treating the gentry, and Cruikshank's caricature (Fig. 2) demonstrates the development of the exclusive nature of the vocation, for his practitioner is not mixing his activities.

Davison's caricatures are particularly valuable, especially that of Hob, the countryman, (Fig. 5) for though the history of the common man is no longer unregarded, evidence is so much scarcer compared with that relating to the 'quality'.
In brief
- Illustration of the developing function of tooth-drawers / dentists independently of other medical disciplines in the eighteenth century.
- Description of the transition of tooth-drawers to dentists during the eighteenth century.
- Demonstration of the fact that the cure of toothache is a universal need.
- As an incidental the paper incorporates a dental 'footnote' to Black history in Britain.

In these six English caricatures, the surgeon and the apothecary do not appear, though it is known that they carried out toothdrawing, as military and ship's surgeons certainly did. The Moskow broadside mentioned earlier, entitled Dicky Gossip's the man showed that under the sign of his pestle and mortar was to be found 'Barber, Dentist, Bleeder, Teeth drawn and others put in, Drugs and Medicines of the best sort, Corns cured, Cloaths made and repaired, and carpentry'. In 1968 a ninety-nine-year-old patient informed me that he had previously inherited his uncle's case of dental instruments, his uncle having been a chemist, and 


\section{GENERAL dental history}

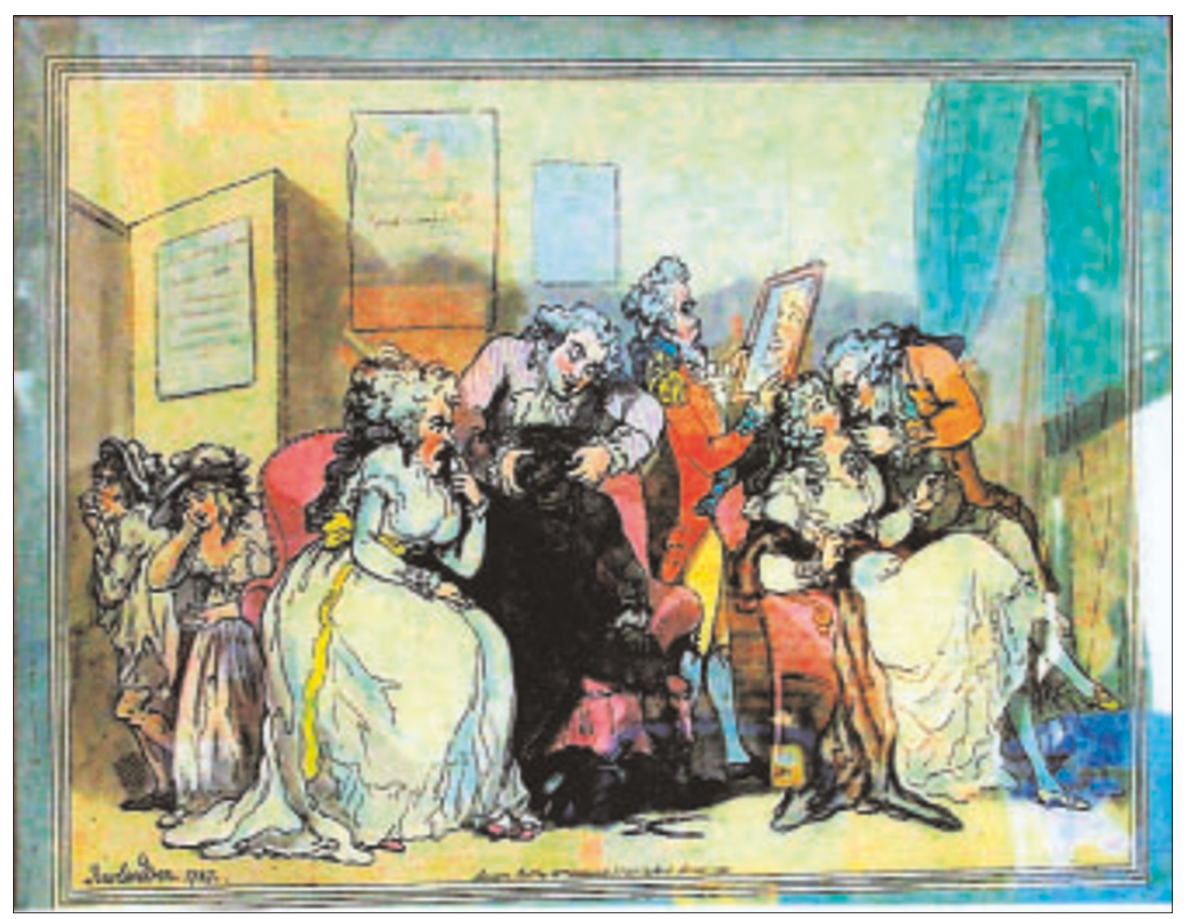

Fig. I Transplanting of teeth. Thomas Rowlandson (I756-I827) I787.

Engraving hand coloured on paper, published I 790 by Wm Holland, London. 33x45 cm. (Private collection. Provenance Messrs Sabin 1967) British Museum Catalogue of political and personal satires No 7766. Other examples in The Royal College of Surgeons of England and the National Library of Medicine, Bethseda USA.

it is still to the chemist that people go to get analgesics.

The caricatures are presented here in the social order of the time, from the 'highest' to the most domestic.

The first print (Fig. 1), entitled Transplanting of teeth is by Thomas Rowlandson (1756-1827) and is dated 1787. It was published by Wm. Holland of No. 50 Oxford Street, in 1790 . The scene is a sparsely decorated room, and presiding among those present is the dentist, 'Baron Rom...' who claims on a placard on the wall to be 'Dentist to Her High Mightyness the Empress of Rusia (sic)'. The description in the British Museum's Catalogue of political and personal satires points out that the two birds on the placard, if they are ducks, draw attention to quackery. The term dentist was then in general use, though in 1759 the Edinburgh Chronicle said 'Dentist figures it now in our newspapers, and may do well enough for a French puffer; but we fancy Rutter is content with being called a toothdrawer' (Samuel Rutter was Master of the Barber Surgeons in 1756). ${ }^{2}$
The 'Baron' is dressed in the height of fashion and is engaged in the extraction of a tooth from a young chimney sweep. His assistant, meanwhile, is occupied in securing a transplanted tooth in the mouth of a good-looking young lady patient, who, hands clenched, is seated in a comfortable arm-chair with a low back. An old male patient is admiring the result of his transplant in a glass, and an older lady patient is waiting to receive one, sharing a two seater settee with the donor, the young sweep in the process of having his tooth extracted.

On the floor in the foreground, in fine defiance of any cleanliness, lies a pair of straight forceps. In the mouth of the sweep the dentist is employing a left-handed and delicate application to an elevator or key in the lower premolar region. The patient's head is supported by the high back of the chair, and by the dentist's right hand.

A raggedly dressed young boy is seen holding his face in the incisor region as he leaves the room, and a ragged young girl holding her cheek in the first molar region looks at the coins in her palm. On the notice on the door is the statement 'Most money given for live teeth', and the implication here that 'dead' teeth were transplanted, and not just used in making dentures, makes considerations of cross infection even more alarming.

This print has been described as ridiculing the vogue for transplantation, but only one of the figures is made ridiculous, the older man in the background. The social comment contained in the caricature is much more strongly directed at the abuse of the poor but virtuous donors (prostitutes while young and beautiful would not have cause to sell their looks for pence) for the benefit of the rich recipients. The dentist may be lampooned by the ducks (if such they be) but he was practising a technique described by Charles Allen in 1685, though damned by him as 'robbing of Peter to pay $\mathrm{Paul}^{3}$ and given scientific validity in the eighteenth century by the experimental work of John Hunter, which had not yet been discredited.

A reflection by Ruth Richardson on this print, and on John Hunter's work in relation to it, appeared in The Lancet in 1999. ${ }^{4}$

The second print (Fig. 2) is entitled Tugging at a high (scored through) eye tooth. The inscription tells us that the idea for it was given by 'A.E.' (identity unknown) and George Cruikshank (1792-1878) did the engraving in his characteristic style. It was published by G. Humphrey of 27, St. James' Street, London, on November 1st 1821. The location this time is the dentist's own rooms, carpeted wall to wall, and the actors in the drama are the dentist, who is engaged in a tussle with the eye tooth in question, while standing on a purposemade stool recognisable in type to those who remember the old gas rooms, and with an arm-lock round the patient's neck.

In the struggle, the female patient, in a high-backed chair, is kicking over a washstand on which stand a hand-mirror, three tooth-scrapers, a decanter, and a glass tumbler, a box (probably of tooth-powder) a full set of dentures, and a mallet. The dog may be assumed to be hers rather than that of the dentist. Hanging in the window is a row of extracted teeth of humorous shape. 


\section{GENERAL dental history}

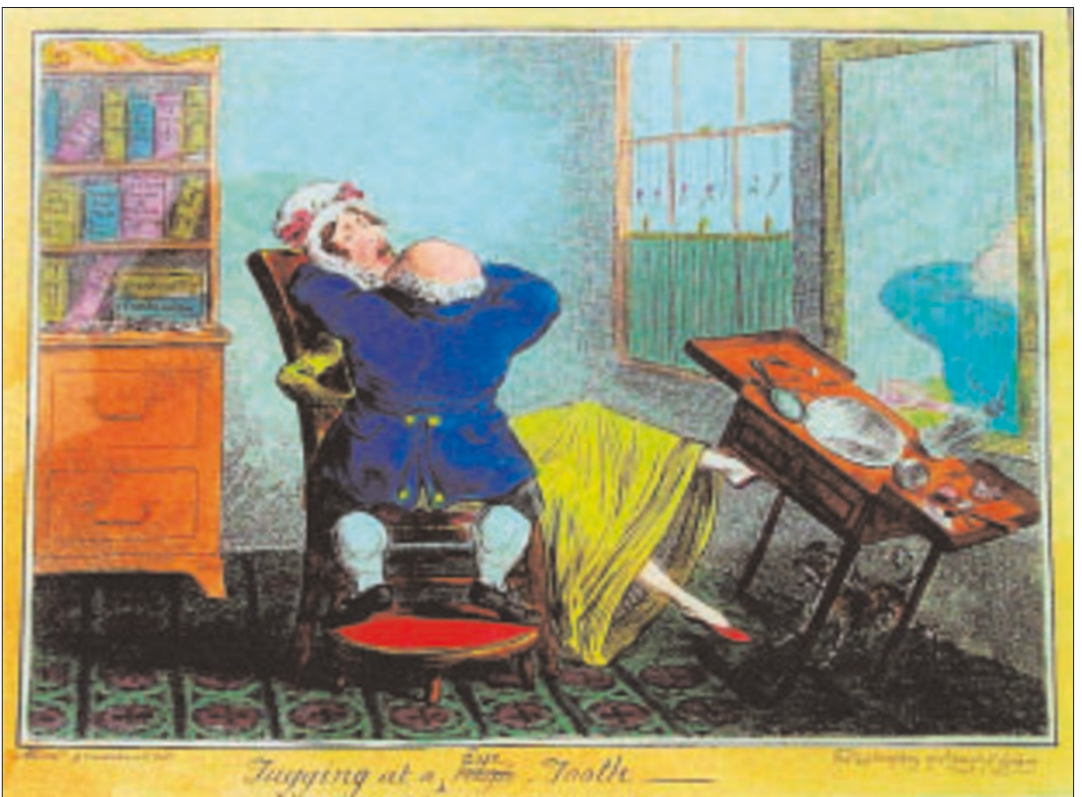

Fig. 2 Tugging at a (high) eye tooth George Cruikshank (1792-1878) from an idea by A. E. (identity unknown) I82I. Engraving hand coloured on paper, published by G. Humphrey, London. $20 \times 25 \mathrm{~cm}$. (Private collection. Provenance The Print Room, Museum Street London. 1986) British Museum Catalogue of political and personal satires No. 1431 I.

Cruikshank obviously enjoyed enhancing the mood of suffering, he added the teeth in the window to an earlier version which did not have them, and on the bookshelf he perhaps adds a sound effect, for on the top shelf are Warbler, Winter in London, Lock on the Gums, Miseries of Human Life, and a copy of The Bible. The middle shelf has Tales of the Devil, Tommy Two Shoes, Treatise on Tooth Powder and Brushes, and Feast of Wit. On the lowest shelf he goes to town with Tales of Terror and Mary Shelley's recently published Frankenstein in two volumes.

Of particular interest are the false teeth, some full/full, and some apparently partial. These may be the porcelain teeth of Dubois de Chémant, described in 1797, and caricatured by Rowlandson in $1811,{ }^{5}$ or may be carved bone or ivory with natural teeth, which came to be known as 'Waterloo' teeth after the grim harvest from the young dead in that battle of 1815 . No springs can be seen on the full sets, and the gum work is clearly pink. Menzies Campbell ${ }^{6}$ quotes Paul Jullion of 47 Gerrard Street, London, as charging $£ 31$. 10s for a full upper or lower set with human teeth in 1781, when an artificial set cost ten guineas - but de Chémant's superior porcelain would have altered that differential.
The third caricature (Fig. 3) appears to move out of London to Alnwick, and could represent any large town or city of the time. Entitled The town tooth drawer, it was printed and published by W(illiam) Davison who, in spite of the old-fashioned nature of the engraving, flourished in the early years of the nineteenth century. This print is a somewhat crude mirror-image re-working of an earlier mezzotint by the prolific caricaturist Edward Dighton (c.1752-1819), which when printed and sold in 1784 by Carington Bowles of St. Paul's Church Yard was entitled The London dentist. ${ }^{7}$ It is interesting that the use of the term dentist should have been dropped in the later print, but this was probably for the sake of matching captions with the companion print to be considered following.

The location is the town house of a lady, and her maid is also present. The British Museum catalogue identifies the site of the Dighton as adjacent to St James' Palace, and Menzies Campbell identifies the operator as a surgeon-dentist named Bartholomew Ruspini who had a house at the other end of Pall Mall. ${ }^{8}$ If Carlton House is shown rather than St James' Palace, Davison has significantly 'de-tuned' the image in transferring it to Alnwick, and it is fortunate for the premise of this essay that he felt he could do so, with the provision of this sort of dental attendance

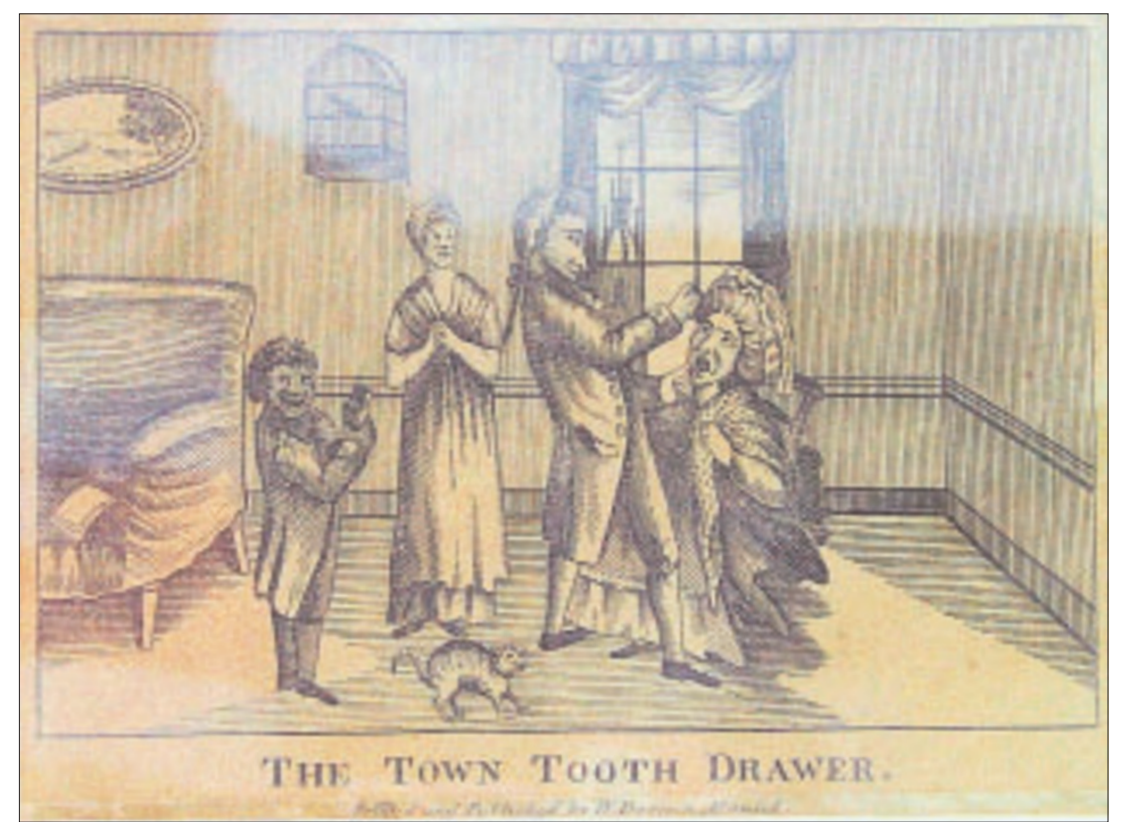

Fig. 3 The town tooth drawer I8I2-18 I7 Copper engraving on paper, printed and published by W Davidson, Alnwick. $16.23 \mathrm{~cm}$ (Private collection. Provenance unknown). After Dighton The London dentist cl 784. British Museum Catalogue of political and personal satires No. 6760. 
appearing realistic in a provincial environment. In 1811 Newcastle upon Tyne, some thirty miles to the south of Alnwick, had two resident dentists, (the term used by Christine Hillam to define those who were more than occasional toothdrawers), Charles Newby Mann in Northumberland Place, and J. Summers in Nungate. ${ }^{9}$ It is perhaps worth noting too that Bartholomew Ruspini's father-in-law Francis Ord (d. 1792), described by Menzies Campbell as being 'noble, wealthy, and of ancient lineage, ${ }^{10}$ had lived thirty miles to the north of Alnwick at Longridge Hall, close to Berwick-upon Tweed.

The frock-coated and bewigged toothdrawer has a young and very cheerful looking Black assistant carrying the instrument case. Considerable numbers of servants and freed slaves did well in Georgian England, two notable examples being Francis (Frank) Barber (1735-1801), who worked for a time at an apothecaries in Cheapside in the 1750s. After a spell at sea, he served Dr Samuel Johnson more as friend than servant for some thirty years, inheriting an annuity of $\mathfrak{E} 70$ on Johnson's death in 1784 . The other, Ignatius Sancho, (1729-1780) who also came to England at a very young age, is worthy of mention in addition to his own literary achievements, for having stimulated one of the finest letters relating to race ever written, ${ }^{11}$ when he contacted Laurence Sterne ${ }^{12}$ asking for his support to protest the evils of slavery. His portrait was painted by Gainsborough. ${ }^{13}$

Davison also has a cat and a canary in attendance, and, where Dighton had a lute and sheet music on the loose-covered settee, has neatly folded towels, while through the window a church spire is seen, rather than a Palace and the bearskins and bayonets of the Guard. The prosperity of the toothdrawer may be gauged by his clothing and wig, his servant, and the possession of the case of specialist instruments.

The next print, (Fig. 4) is another engraving by Davison of Alnwick. Entitled The country tooth drawer it is the companion print to the previous example, and is an almost exact copy of an earlier Dighton mezzotint ${ }^{14}$ of the same title. The only major difference is that again it is

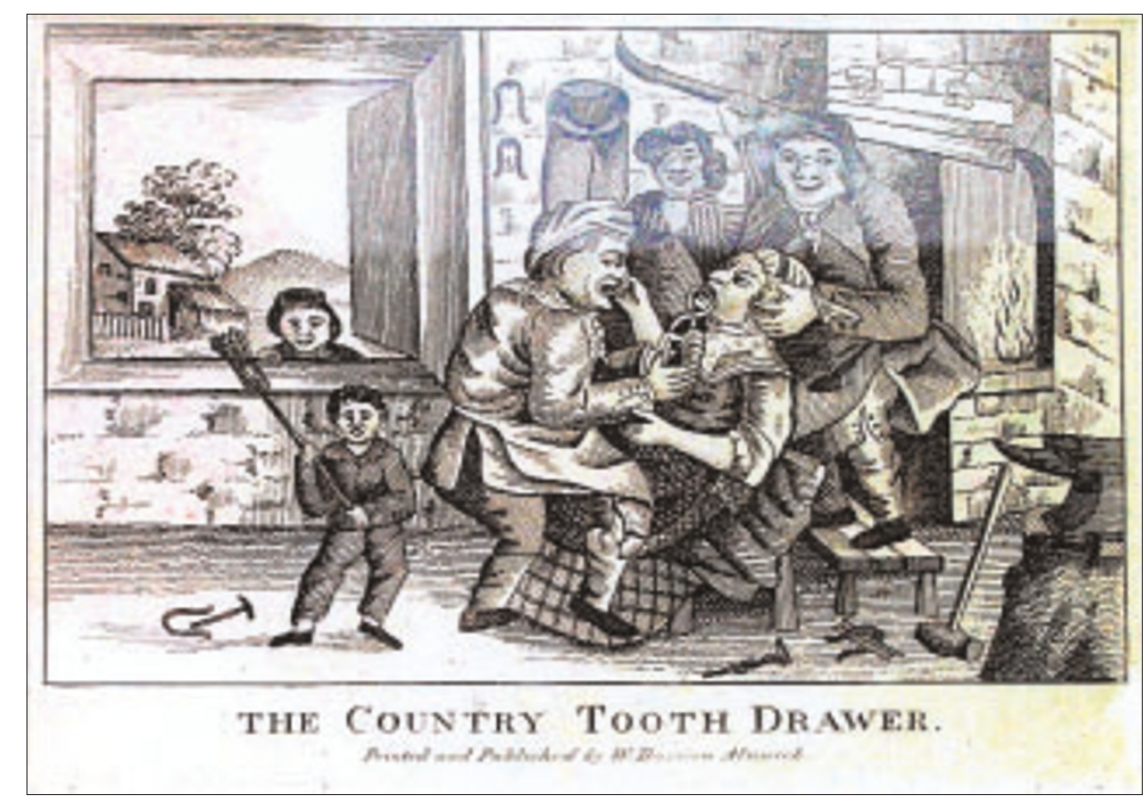

Fig. 4 The country tooth drawer 1812-1817 Copper engraving on paper, printed and published by W Davison, Alnwick. $16 \times 23 \mathrm{~cm}$ (Private collection. Provenance The Print Room. Museum Street London. 1990) After Dighton. c. I 784. The country tooth drawer British Museum Catalogue of political and personal satires No 6759.

a mirror image. In both we are taken to a village smithy, where the blacksmith acting as dentist is drawing an incisor with a two handed grip on a large pair of pliers or pincers, very much not a specialist instrument.

His assistant, standing on a stool to support the patient's head against his chest, is providing a good steadying and immobilising hold, as used to this day. The goodwife patient, with a firm grip of the blacksmith's nose, is seated on a stool, while a one-eyed man is either keeping the bellows of the forge going, or waving an agricultural implement, possibly a billhook. A boy with a very unhappy expression, possibly the woman's son, is either just carrying a besom or using it to belabour the blacksmith. Through an unglazed window a cottage is seen, and an amused boy is looking in at the scene.

It is likely that in reality a village blacksmith or farrier would acquire a considerable degree of skill in extracting teeth. John Woodforde, in his 1968 book The strange story of false teeth, relates that his namesake Parson Woodforde, the diarist, called in the village farrier to extract a tooth for him in 1776. ${ }^{15}$
Print number five (Fig. 5) is of interest in its portrayal of an itinerant toothdrawer. Entitled Hob and stage doctor, it is the third print by Davison. The location is a public stage on which appears a mountebank or quack doctor in a tricorne hat and full wig, engaged in drawing a lower incisor tooth. He has a headlock on the smartly dressed patient (Hob, the countryman) who is wearing knee-britches, and has his hat beside him. Meanwhile the mountebank's assistant is capering about with a clay pipe and goblin or clown's costume, both to provide additional entertainment and distraction, and no doubt to collect money.

Round the stage is a crowd of some three dozen men, most amused, some horrified. The position of the patient allows for a moderately satisfactorily operating position, (and had been advised and illustrated by Ludwig Cron in his book on bloodletting and toothdrawing Aderlassen und Zahnauszieben in 1717 ${ }^{16}$ particularly where, as here, the hand position of the operator shows that a 'key' is likely to have been the specialist instrument being used, which does not require the degree of head fixation needed for forceps. 


\section{GENERAL dental history}

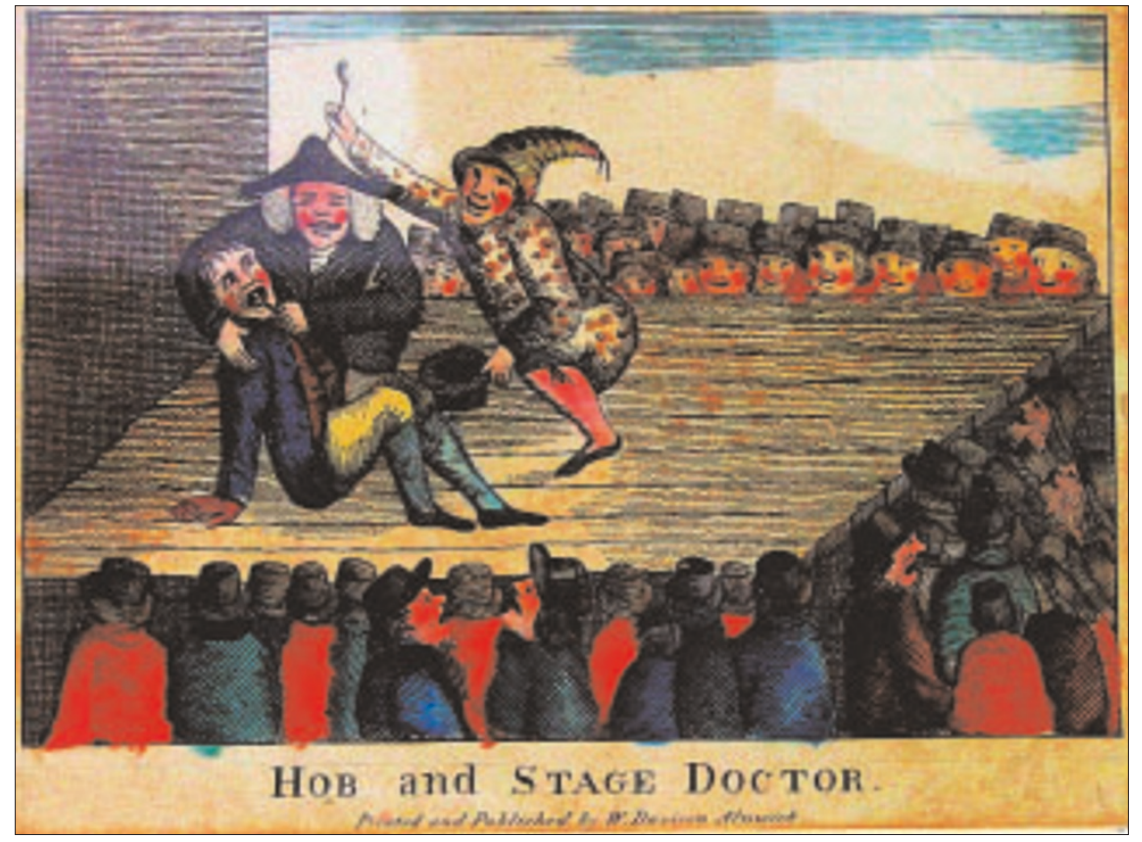

Fig. 5 Hob and stage doctor I8 I2- I 817 Copper engraving on paper, printed and published by W Davison, Alnwick. I6×23cm (Private collection. Provenance Messrs Bloch, Barter Street, London 1968).

Reinforcing this is the fact that a left handed operating position has been adopted, something to which the key is particularly well adapted. This may merely be the result of the engraving having been reversed, as this is known to have happened to the Country tooth drawer, though this interpretation would make the assistant left-handed.

The series finishes with a domestic scene, derived from a grouping which had a long pedigree as a dental caricature (Fig. 6). The title is Fellow feeling, published on June 4th 1812 by Edwd. (Edward) Orme of London, an accomplished caricaturist, but the characters started 'life' in The ludicrous operator, or Blacksmith turn'd tooth drawer, by Harris and Dixon in 1768, which is used as an illustration in Christine Hillam's The roots of dentistry, ${ }^{17}$ and the 'family' is also identifiable in parts of the Dighton and the Davison prints.

The Orme re-working by taking the characters indoors illustrates the position of last resort for those without access to a toothdrawer or dentist, it shows the relief of dental pain in a scene the type of which was related to me by one of my own patients, one of five brothers living in Hertfordshire in the mid twentieth century. When one needed a tooth drawing a maxillary incisor with a twohanded grip on a large pair of pincers. The elderly female patient, clutching her hat in one hand and one arm of the wooden armchair in which she is seated in the other. Her presumed husband leans on the back of the 'dentist's' chair with empathy in every line of his face.

The likelihood of decoronation in this caricature, as in the Davison Country tooth drawer seems very high, but the risk of cross infection is at the lowest for this patient. It would have been very high for those attending a specialist who treated his instruments in the way that Rowlandson shows. It should not though be assumed in the light of that print that all our forerunners did not care for their instruments, Lilian Lindsay gives an account of the spotless cleanliness of the shop of James Spence, protégé of John Hunter and in practice in the eighteenth century.

Apart from his cavalier way with forceps, the risk of cross infection would in any case be highest for those visiting the 'Baron' for transplantation, although the youthfulness of the donors might have given some protection. A horrifying account is given in Ruth Richardson's Lancet paper ${ }^{4}$ of a case of seated in a comfortable upholstered chair, out, three held him in a wheelbarrow, while the last used a pair of pliers to operate.

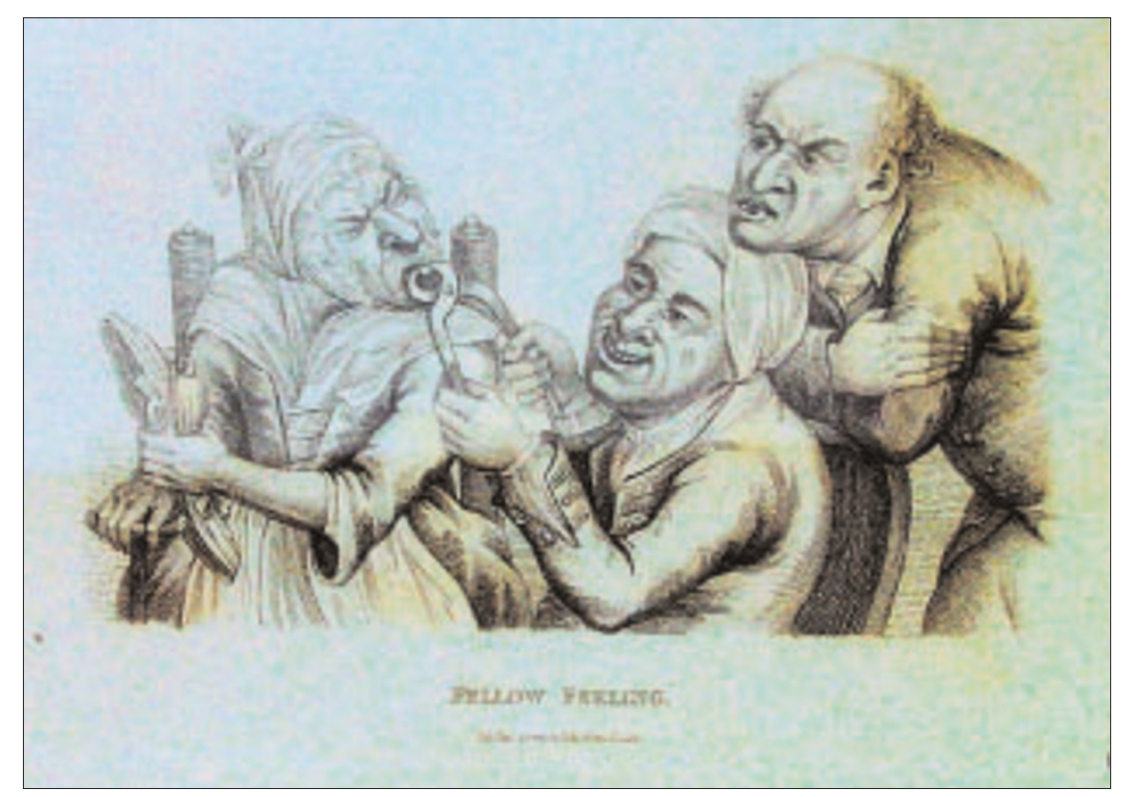

Fig. 6 Fellow feeling 1810 Engraving on paper. Published by Edwd. Orme, London. $16 \times 20 \mathrm{~cm}$ (Private collection. Provenance Messrs Bloch, Barter Street, London 1968). Possibly a re-working of a theme The ludicrous operator, or Blacksmith turned toothdrawer attributed to Dixon after Harris, 1768, or The village doctor, or Blacksmith turned tooth toothdrawer with a possible attribution to Dighton. The last is in the British Museum Catalogue of political and personal satires No 805I. 
syphilis acquired by a young female patient following transplantation in 1785.

The study of the history of dentistry depends to a certain extent on the survival of ephemera. That these examples of the scarce and now rare caricatures produced around two hundred years ago should have lasted long enough to give such a broad idea of the availability of dental care to the English population of the time is quite remarkable. That they carry with them incidental detail which allows for an assessment of ethical, emotional, and professional background in some depth is a decided bonus.

The authors are most grateful to Mr Des Arbon for the photography.

All prints in Private Collection, England. The location of other prints or copies where available is detailed in text.
1 Murray's English Dictionary (now the Oxford English Dictionary) 1890 p 200.

2 Lindsay L. A short history of dentistry. p 57. London: John Bale, Sons and Danielsson, Ltd. 1933.

3 Allen C. The operator for the teeth. York, 1685. Section IV p 11. Reprinted with an introduction by R A Cohen in a limited edition. Dawson's of Pall Mall, 1969.

4 Richardson R. Transplanting teeth. Lancet 1999; $354: 1740$.

5 British Museum Catalogue of political (personal) and social satires. 11798.

6 Campbell M. Dentistry then and now. In Woodforde J. The strange story of false teeth. p 28. London: Routledge \& Keegan Paul, 1968.

7 British Museum Catalogue of political (personal) and social satires. 6760.

8 Campbell J M. From a trade to a profession: Byways in dental history. pp32-33. Private printing. 1958.

9 Hillam F C. The development of dental practice in the Provinces from the late 18th Century to 1855. Unpublished $\mathrm{PhD}$ thesis. University of Liverpool. July 1986.
10 Campbell J M. From a trade to a profession: Byways in dental history. $\mathrm{p} 20$. Private printing. 1958.

11 Sterne L. Letter XXXII. Letter to Ignatius Sancho. Coxwould (sic) 1766. In Knox V (ed). Elegant epistles. London: Charles Dilly, 1790.

12 Sancho I. Letter XXXI. Letter to Mr. Sterne 1766. In Knox, V. (ed). Elegant epistles. London: Charles Dilly, 1790.

13 Dictionary of National Biography, and The Black Presence in Britain:

http://www.blackpresence.co.uk/html/ sanch.htm

http://www.blackpresence.co.uk/html/ barber.htm

14 British Museum Catalogue of political (personal) and social satires. 6759

15 Campbell M. Dentistry then and now. In Woodforde J. The strange story of false teeth. p34. London: Routledge \& Keegan Paul, 1968.

16 Ring M E. Dentistry, an illustrated history. p.166. New York: Harry N Abrams, Inc., 1985

17 Hillam C. (ed). The roots of dentistry. p 36. London: BDJ publications 1990. 